JURNAL SAINS DAN INFORMATIKA

RISEARCH OF SCIENCE AND INFORMA'IC v7.I2

Vol.07 No.02(2021)36-43

http://publikasi.lldikti10.id/index.php/jsi/

p-issn : 2459-9549

e-issn : 2502-096X

\title{
Pemanfaatan Barcode Scanner Pendaftaran Pasien Pada Puskesmas Rawat Inap Way Kandis
}

\author{
Didi Susianto $^{(\mathrm{a})}$, Eka Ridhawati $^{(\mathrm{b})}$, Yuli Syafitri $^{(\mathrm{c})}$ \\ aProgram Studi Sistem Informasi, STMIK Pringsewu, Lampung, di2.susianto@gmail.com \\ bProgram Studi Sistem Informasi, STMIK Pringsewu, Lampung, ekaridhawati@ gmail.com \\ Program Studi Manajemen Informatika, AMIK Dian Cipta Cendikia, ayulisyafitri@gmail.com
}

Submitted: 23-10-2021, Reviewed: 24-11-2021, Accepted 29-11-2021

http://doi.org/10.22216/jsi.v7i2.638

\begin{abstract}
Way Kandis Inpatient Health Center as a provider of health care facilities are required to provide fast and accurate health services. The problem currently faced is patient service which includes patient registration, patient data processing, and report data processing which is still done manually so that it is ineffective and slows down or complicates registration officers in serving patients. The system development method used by the author for this research is the Extreme Programming method. The stages of the Extreme Programming (XP) method are: planning, designing, coding, testing and improving software. The design tool uses a UML diagram that consists of use case diagrams, class diagrams, and activity diagrams. From this research, a barcode scanner based on patient registration information system is produced which is able to process registration data, print queue evidence, process patient data, print barcode patients, and process reports better than the old system. Testing the system in this study using a black box where the system developed at the Way Kadis Health Center was tested by data entry by the actors involved in the inpatient process. The system built can simplify and help to improve the performance of registration officers in serving patients at Way Kandis Inpatient Health Center quickly, and accurately.
\end{abstract}

Keywords: Barcode Scanner, Extreme Programming (XP), (Health Center) Puskesmas, Patient Registration

\begin{abstract}
Abstrak
Puskesmas Rawat Inap Way Kandis sebagai penyedia layanan kesehatan harus menyediakan layanan kesehatan yang cepat dan akurat. Permasalahan yang ada saat ini adalah pelayanan pasien yang meliputi registrasi pasien, pengolahan data pasien, dan pengolahan data laporan masih dilakukan secara manual sehingga tidak efisien dan lambat, sehingga mempersulit bagian pendaftaran untuk melayani pasien. Dalam pengembangan sistem yang dibangun, penulis menggunakan metode Extreme Programming $(X P)$. Tahapan-tahapan metode Extreme Programming $(X P)$ adalah: perencanaan, perancangan, pengkodeean, pengujian dan peningkatan perangkat lunak. Alat desain memanfaatkan diagram Unified Modeling Language (UML) yang mencakup diagram use case, diagram kelas, dan diagram aktivitas. Sistem informasi pendaftaran pasien sangat dibutuhkan untuk mendukung aktivitas registrasi dan pengolahan data di bidang kesehatan. Salah satu penerapan dalam aplikasi ini adalah membantu menyimpan dan mengolah data pasien di Puskesmas Rawap Inap Way Kandis. Tujuan dari penelitian ini menghasilkan sistem informasi registrasi pasien berbasis barcode scanner yang mampu mengolah data registrasi, mencetak bukti antrian, mengolah data. pasien, mencetak kartu pasien dengan barcode, dan memproses laporan lebih baik daripada sistem lama. Pengujian sistem pada penelitian ini menggunakan black box dimana sistem yang dikembangkan pada Puskesmas Way Kadis dilakukan pengujian dengan cara pengentrian data oleh para aktor yang terlibat dalam proses rawat inap. Sistem yang dibangun ini dapat mempermudah dan membantu meningkatkan kinerja pendaftar untuk melayani pasien rawat inap Puskesmas Way Kandis secara cepat, tepat dan akurat.
\end{abstract}

Keywords: Pendaftaran Pasien, Puskesmas, Barcode Scanner, Extreme Programming (XP)

(C) 2018 Jurnal Sains dan Informatika 


\section{Pendahuluan}

Saat ini, teknologi berkembang pesat, begitu pula Ada beberapa referensi dalam penelitian ini sebagai dengan peningkatan teknologi informasi. Teknologi acuan penulis, yaitu: informasi dibutuhkan untuk memudahkan tugas manusia, termasuk di bidang kesehatan [1]. Sebagai penyedia fasilitas kesehatan, Puskesmas berkomitmen untuk memberikan layanan kesehatan yang cepat dan akurat. Oleh karena itu, kemajuan teknologi di bidang kesehatan harus dimanfaatkan oleh puskesmas untuk memenuhi kebutuhan pelayanan tersebut.

Sistem informasi pendaftaran pasien sangat dibutuhkan untuk mendukung aktivitas registrasi dan pengolahan data di bidang kesehatan. Salah satu penerapan dalam aplikasi ini adalah membantu menyimpan dan mengolah data pasien di Puskesmas Rawap Inap Way Kandis. Sistem informasi pendaftaran pasien ini dibangun dengan bahasa pemrograman PHP, program Sublime / Notepad ++ dan database MySQL. Metode pengambilan data pada penelitian yang dilakukan adalah observasi, wawancara, dan metode kepustakaan. Metode pengembangan sistem menggunakan Extreme Programming (XP).

Sistem informasi ini untuk Puskesmas Rawat Inap Way Kandis. Sistem yang saat ini digunakan di semua proses puskesma, seperti registrasi pasien, pengolahan dan pelaporan data pasien, belum diterapkan secara efektif. Nyatanya, hal ini memperlambat dan mempersulit pekerjaan para karyawan. Misalnya untuk mendaftar, masukkan informasi dan laporan pasien. Oleh karena itu untuk mengatasi permasalahan di Puskesmas Rawat Inap Way Kandis dapat dilakukan dengan membuat sistem informasi yang cepat dan akurat.

Penelitian ini dilakukan dengan tujuan untuk merancang dan membuat sistem informasi pendaftaran pasien di Puskesmas Rawat Inap Way Kadis dengan memanfaatkan barcode scanner. Sistem informasi ini mengelola banyak proses, termasuk memasukkan catatan pasien menggunakan pembaca kode batang, memproses data pasien, dan kemampuan sistem untuk melihat laporan secara otomatis. Tujuan utama pembangunan sistem informasi ini adalah untuk mengajukan sistem informasi registrasi pasien dan membuat kartu pasien dengan barcode di Puskesmas Rawap Inap Way Kandis. Keuntungan dari penelitian ini baik secara langsung maupun tidak langsung, artinya dengan adanya sistem informasi ini dapat mengatasi permasalahan tersebut di atas dan mempercepat serta memudahkan petugas Puskesmas khususnya dalam melakukan registrasi pada pasien.

\section{Tinjauan Pustaka/Penelitian Sebelumnya}

Dalam mendukung penelitian ini, tentu saja merujuk kepada beberapa penelitian terdahulu sebagai bahan acuan penulis.

\subsection{Penelitian Terkait}

a. Penelitian yang dilakukan oleh Yuyi Andrika dengan judul "Penerapan Model Waterfall Pada Sistem Informasi Rawat Jalan Dengan Kartu Pasien BerBarcode Studi Kasus : Puskesmas Kenanga Sungailiat" pada Journal of Computer Science and Information System, pada tahun 2017. Dilakukannya penelitian ini karena masalah pencatatan manual, pencarian pasien dan rekam medis membutuhkan waktu lama. Pada penelitian ini dihasilkan sistem informasi yang dapat merekam lebih cepat, mempermudah pencarian data, dan mencetak laporan setiap saat [2]

b. Penelitian dengan judul: "Sistem Informasi Kabupaten Pekalongan Berbasis Android" yang dilakukan oleh Aslan dan Dwi yaitu untuk mengatasi masalah adanya antrian pada saat pendaftaran. Adapun hasil dari penelitianya, yaitu menghasilkan sistem informasi pendaftaran berbasis android. Dalam mengembangkan aplikasi peneliti menggunakan framework Ionic dan framework AngularJS sebagai front-end, PHP sebagai back-end, dan MySQL sebagai database. Sistem ini dibuat dengan beberapa fasilitas-fasilitas yang dapat digunakan, diantaranya untuk mendaftar periksa dan juga ada pemberitahuan untuk mengetahui nomor antrian. Dalam aplikasi ini, user dapat mendaftarkan beberapa pasien dalam satu akun. Aplikasi ini dapat menulis keluhan pasien yang akan mendaftar periksa [3]

c. Penelitian yang dilakukan oleh Pradikta Andrianto dengan judul "Sistem Informasi Pelayanan Kesehatan Berbasis Web di Puskesmas" Prosiding Seminar Nasional Komputer dan Informatika (SENASKI) 2017. Permasalahan dalam penelitiannya adalah sulitnya mencari rekam medis, pelayanan yang tidak efisien dan rekam manual. Hasil penelitian ini memberikan informasi grafik pasien, informasi antrian pasien, informasi resep obat, dan informasi laporan pasien [4]

d. Penelitian oleh Akhmad Syukron, Noor Hasan dengan judul "Perancangan Sistem Informasi Rawat Jalan Berbasis Web Pada Puskesmas Winong", terdapat pada Jurnal Bianglala Informatika tahun 2015. Permasalahan: Registrasi pasien masih terjadi masalah pada identifikasi pasien lama dan baru, dan pembuatan laporan masih dilakuan secara manual. Hasil penelitian : Menghasilkan aplikasi sistem informasi yang lebih baik. Ini membantu kinerja

e. Penggunaan aplikasi adalah untuk pelayan medis dokter sebagai bagian informasi yang disediakan oleh Kimia Farma Bireuen. Perancangannya menggunakan fungsi FIFO, dengan single channel (satu pintu) atau ports yang diperlukan. Diharapakan Pendaftaran Pasien pada Klinik dr. Veri Kajen puskesmas dalam pemrosesan dan pelaporan data [5] 
dengan adanya sistem ini dapat membantu pelayanan kepada pelanggan dengan tingkat pelayanan yang sama. Sistem pendaftaran onlie pasien pada klinik dengan metode FIFO berbasis web service dapat membantu pelanggan untuk mengetahu informasiinformasi tentang pelayanan kesehatan di klinik tersebut [6]

f. Hasil dari penelitian ini berupa aplikasi absensi mahasiswa yang menggunakan QR code sebagai media masukan kehadiran mahasiswa berbasis jaringan lokal yang diimplementasikan agar terciptanya sebuah sistem informasi absensi yang memberikan kemudahan mahasiswa dalam proses absensi, mengurangi tindak kecurangan yang dilakukan oleh mahasiswa, serta memudahkan laporan ketika melakukan rekapan laporan [7]

\subsection{Teori Pendukung}

a. Sistem Informasi

Sistem informasi adalah sistem yang bertujuan untuk menghasilkan informasi. Informasi adalah data yang diolah dalam format yang berguna bagi pengguna [8].

b. Pendaftaran

Pendaftaran adalah sebuah proses pencatatan seperti pencatatan identitas, alamat dan sebagainya dalam daftar. Berdasarkan pemahaman di atas peneliti dapat menyimpulkan bahwa pendaftaran adalah proses pencatatan identitas bagi setiap pendaftar ke dalam sebuah media penyimpanan yang digunakan dalam proses pendaftaran [9].

\section{c. Barcode}

Barcode adalah kode identifikasi khusus yang dicetak, berupa rangkaian batang vertikal tercetak yang berbeda lebarnya dan mewakili angka-angka [10]. Kode batang (barcode) adalah garis yang berisi kombinasi lebar garis dan spasi garis paralel, dan disebut kode batang satu dimensi. Kode batang dengan kotak, titik, segi enam, dan bentuk geometris lainnya, di sisi lain, dapat disebut kode batang dua dimensi [10].

d. Pemindai

Pemindai adalah alat yang digunakan untuk memeriksa atau mengamati data yang direkam; alat untuk memindai sesuatu.

\section{Metodologi Penelitian}

Pengembangan perangkat lunak menggunakan berbagai pendekatan dan metode. Dalam penelitian ini, aplikasi pendaftaran pasien dibuat dengan menggunakan metode Extreme Programming (XP). Tahapan-tahapan metode Extreme Programming, seperti terlihat pada gambar 1.

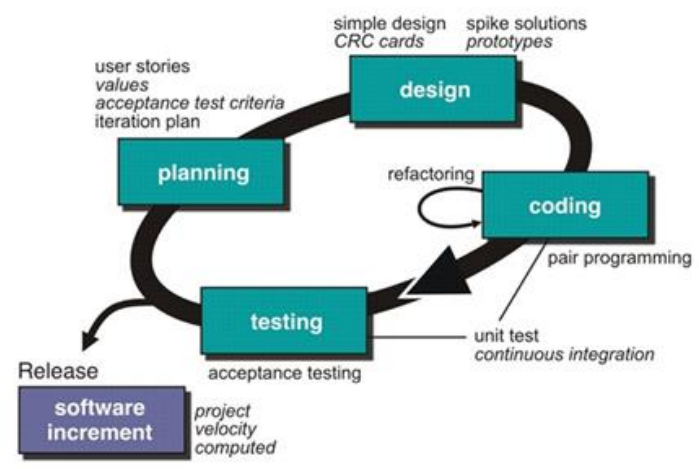

Gambar 1. Metode Extreme Programming (XP)

Adapun tahapan-tahapan yang harus dilaksanakan dan dikerjakan pada metode extreme programming (xp) yaitu: [9]

a. Planning (Perencanaan)

Tahapan ini merupakan langkah awal dalam pengembangan sistem yang meliputi beberapa kegiatan perencanaan seperti identifikasi masalah, analisis kebutuhan dan perencanaan implementasi pengembangan sistem.

\section{b. Design (Perancangan)}

Pada tahap perancangan, dibuat model sistem berlandaskan hasil analisis kebutuhan yang diterima. Selain itu, melakukan pemodelan database untuk mengilustrsikan keterkaitan data. Model sistem digunakan adalah Unified Modeling Language (UML).

\section{c. Coding (Pengkodean)}

Langkah ini merupakan kegiatan pemodelan yang dibuat pada antarmuka pengguna dengan menggunakan bahasa pemrograman. PHP adalah bahasa pemrograman yang digunakan dalam penelitian. Sedangkan sistem manajemen basis data menggunakan perangkat lunak MySQL.

d. Testing (Pengujian)

Langkah ini merupakan langkah pengujian aplikasi terintegrasi. Pada titik ini didefinisikan oleh pengguna sistem dan berfokus pada karakteristik dan fungsi dari kesemua sistem, yang kemudian sistem diverifikasi oleh pengguna. Metode verifikasi aplikasi pendaftaran pasien adalah menguji black box dengan menguji input dan output dari sistem yang dikembangkan.

e. Software Increment (Peningkatan Perangkat Lunak) Tahapan ini merupakan tahapan pengembangan sistem, yang dilakukan secara bertahap setelah sistem diperkenalkan ke dalam organisasi, dengan penambahan layanan atau konten, yang mengarah pada peningkatan fungsi sistem. 


\subsection{Analisis Kebutuhan Sistem}

Analisis sistem didefinisikan sebagai penyelesaian seluruh sistem sebagai komponen untuk mengidentifikasi masalah. Setelah melakukan tahap perencanaan dan desiain system, maka tahap berikutnya adalah melakukan analisis sistem [11]

\subsubsection{Perangkat Lunak (Software)}

Perangkat lunak adalah program tambahan yang dimanfaatkan dalam menjalankan perangkat keras. Program yang dimanfaatkan untuk membangun sistem informasi di puskesmas ini yaitu: 1) Windows 7 atau lebih tinggi sebagai sistem operasi, 2) Xampp, 3) Script Editor digunakan adalah sublime dan notepad ++, 4) Firefox / Google Chrome sebagai browser web.

\subsubsection{Perangkat Keras (Hardware)}

Perangkat keras (hardware) adalah perangkat komputasi fisik. Perangkat keras (hardware) dibutuhkan untuk mengimplementasikan desain sistem [9]. Spesifikasi perangkat keras yang diperlukan untuk membangun sistem ini meliputi: 1) Prosesor Intel Dual-Core minimal, 2) RAM minimum 2GB, 3) 500 GB hard drive, 4) Keyboard standar sebagai perangkat input, 5) Pemindai kode batang sebagai pemindai kode batang.

\subsubsection{Use Case}

Dalam sistem terintegrasi, digunakan use case diagram yang menggambarkan hubungan antara aktor dan sistem [12]. Penggunaan use case diagram menggambarkan interaksi beberapa aktor dari sistem yang dikembangkan.

Use case diagram admin/petugas manggambarkan fungsi atau layanan apa saja yang bisa digunakan oleh administrator dari aplikasi system pendaftaran pasien. Untuk melakukan pengolahan data pengguna, admin diharuskan login. Jika berhasil makan akan masuk ke halaman administrator. Dalam halaman admin, administrator dapat melakukan pengolahan data pendaftaran dan biaya pasien, mengolah data pasien, mengolah data poli, mengolah data dokter, dan mengolah data laporan.

Perancangan use case pada sistem yang akan dibangun dapat dilihat pada gambar 2 di bawah ini.

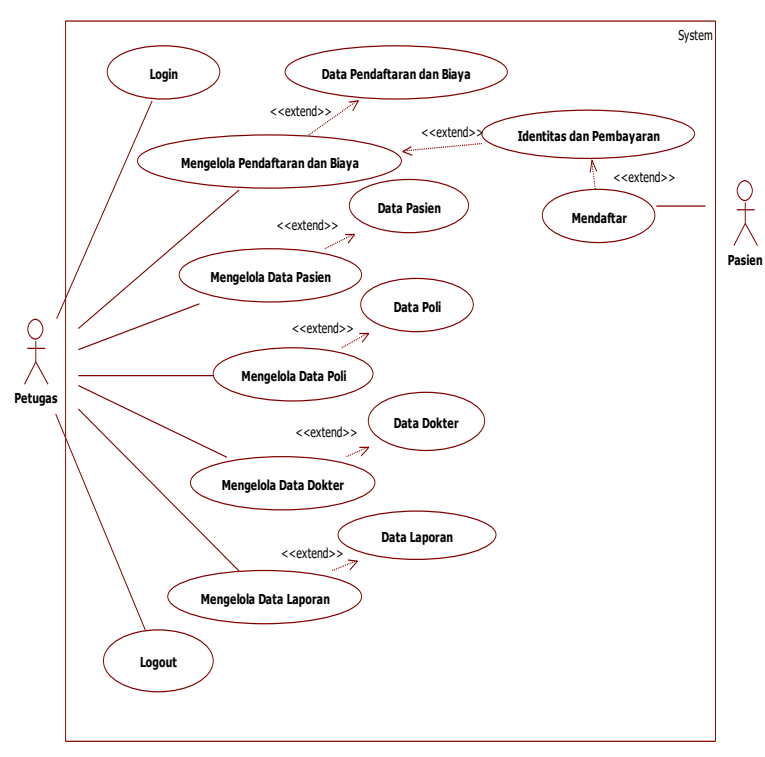

Gambar 2. Perancangan Use Case

Berdasarkan gambar 2. diatas yang menjelaskan tentang rancangan usecase pada system informasi pendaftaran pasien menggunakan scan Barcode memiliki dua orang yang memiliki hak akses yaitu petugas aatau admin dan Pasien. Dimana masing-masing memiliki menu yang berfungsi sesuai dengan kegiatan dari masing-masing user.

Untuk Petugas atau admin memiliki lima menu pengolahan data yaitu :

a. Menu mengelola pendaftaran dan biaya memiliki fungsi untuk melayani pendaftaran pasien baru dan mencatat penerimaan biaya pendaftaran berobat pasien baru maupun lama.

b. Menu mengelola data pasien, memiliki fungsional yaitu mencatat dan merekap dan menginfrmasikan rekaman data pasien berobat

c. Menu mengelola data poli, memiliki fungsi untuk menngelola data poli yang terdapat di puskesmas

d. Menu mengelola data dokter, memiliki fungsi untuk mencatat dan menampilkan informasi data dokter yang praktek di puskesmas

e. Menu Mengelola data laporan, memiliki fungsi untuk mencetak laporan yang dibutuhkan oleh manajemen

Untuk pasien hanya memiliki satu fungsional untuk mengakses system yaitu hanya berfungsi untuk melakukan pendaftran bagi pasien yang sudah memiliki kartu berobat yang dilengkapi dengan barcode. Pasien dapat melakukan pendaftaran sendiri dengan kartu tersebut dan bisa melihat tampilan jadwal dokter dan poli yang praktek di puskesmas. Pasien bisa melakukan pendaftaran secara langsung dan bisa mendapatkan kartu pendaftaran yang digunakan untuk antrian berobat. 


\subsubsection{Class Digram} Diagram yang mengilustrasikan deskripsi dan struktur Profile, dan Laporan. Adapun tampilan menu utama serta hubungan antar diagram kelas pada sistem terlihat di gambar 5.

informasi pendaftaran pasien dapat dilihat pada gambar 3.

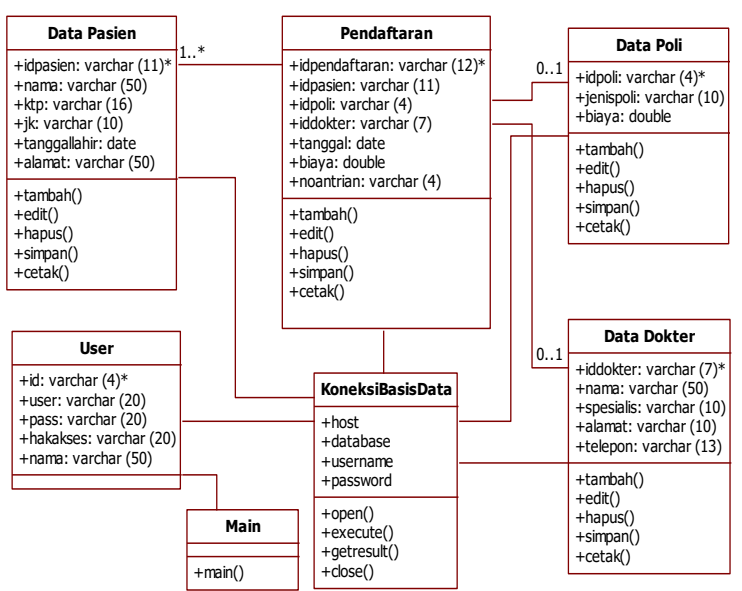

Gambar 3. Perancangan Class Diagram

\section{Hasil dan Pembahasan}

Penelitian ini menghasilkan Sistem Informasi Pendaftaran Pasien Berbasis Barcode yang memiliki beberapa fitur, adapun fitur pada sistem ini sebagai berikut : 1) Program ini memiliki fitur yang dapat mengolah data pasien dan dapat menghasilkan kartu pasien berbarcode. 2) Program ini memiliki fitur yang dapat mengolah data poliklinik, dan data dokter. 3) Program ini memiliki fitur yang dapat mengolah data pendaftaran dan menghasilkan nomor antrian berbarcode. 4) Program ini memiliki fitur yang dapat mengolah data laporan perpriode.

\section{a. Tampilan Login}

Tampilan form ini, berfungsi untuk keamanan data dan dimana administrator diminta untuk memasukan username dan password yang telah ditentukan. Adapun tampilan form login dapat dilihat pada gambar 4 .

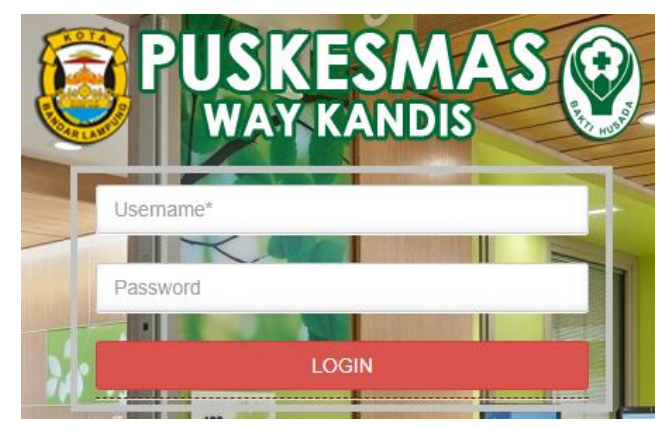

Gambar 4. Tampilan Form Login
Tampilan Menu Utama atau beranda adalah halaman utama yang terdiri dari Beranda, Pendaftaran, Master,

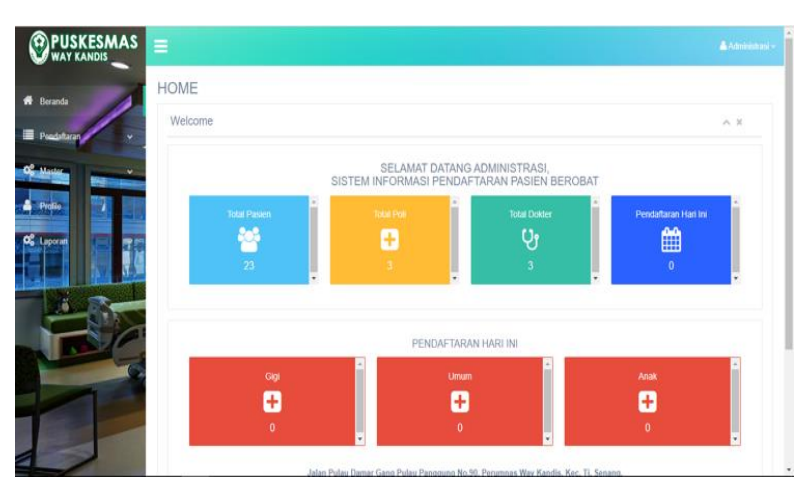

Gambar 5. Tampilan Menu Utama / Beranda

\section{c. Tampilan Pendaftaran}

Tampilan Pendaftaran berikut ini berisi daftar pendaftaran pasien yang terdiri dari, id pendaftaran, tanggal daftar, nomor antrian, nama pasien, poliklinik, nama dokter, dan biaya. Adapun tampilan pendaftaran ini terlihat di gambar 6.

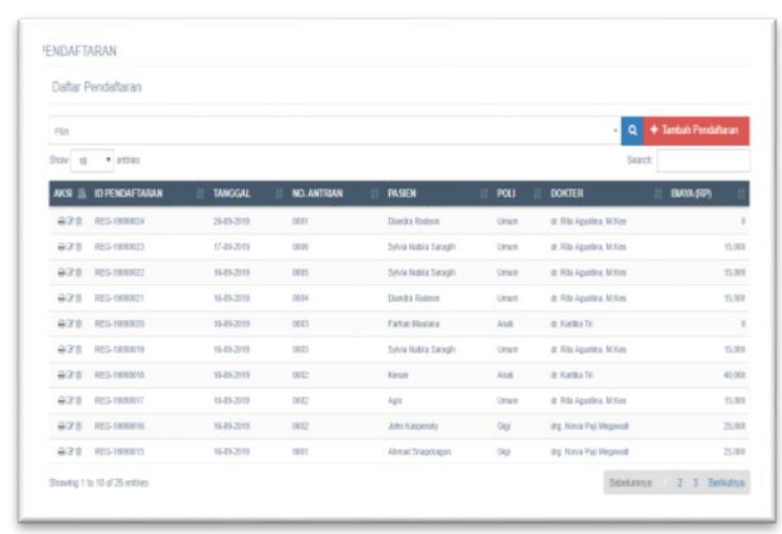

Gambar 6. Tampilan Pendaftaran Pasien

\section{d. Tampilan Tambah Data Pendaftaran}

Tampilan ini berfungsi untuk menambah data pendaftaran pasien berobat yang terdiri dari, id pendaftaran, poliklinik, scan barcode kartu pasien, dan pilih pasien apabila pasien pernah daftar namun tidak membawa kartu pasien, selanjutnya pilih dokter. Adapun tampilan tambah data pendaftaran pasien ini dapat dilihat pada gambar 7 dan 8 .

\section{b. Tampilan Menu Utama / Beranda}




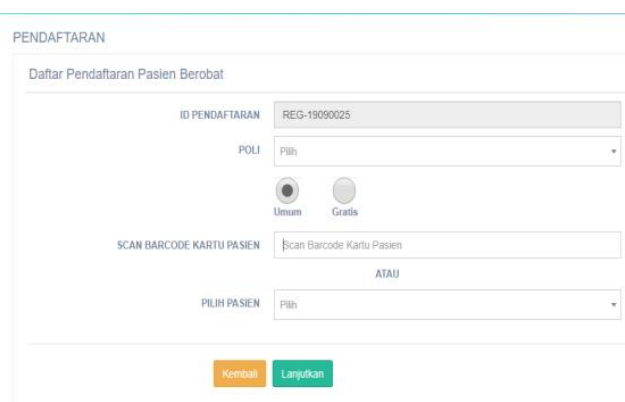

Gambar 7. Tampilan Tambah Data Pendaftaran

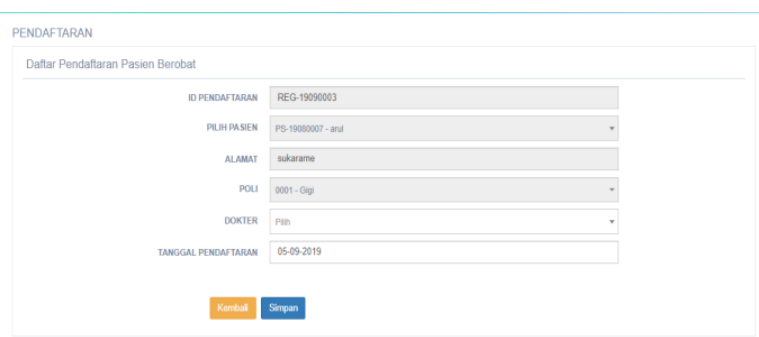

Gambar 8. Tampilan Tambah Data Pendaftaran

\section{e. Tampilan Hasil Cetak Antrian}

Tampilan ini merupakan hasil cetak bukti dan nomor antrian untuk diberikan ke poliklinik yang dituju, terdiri dari nomor antirian, id pasien dan barcode, nama, alamat, tanggal daftar, poliklinik, dokter, biaya, dan terbilang. Adapun tampilan hasil cetak bukti pendaftaran dan antirian ini terlihat di gambar 9.

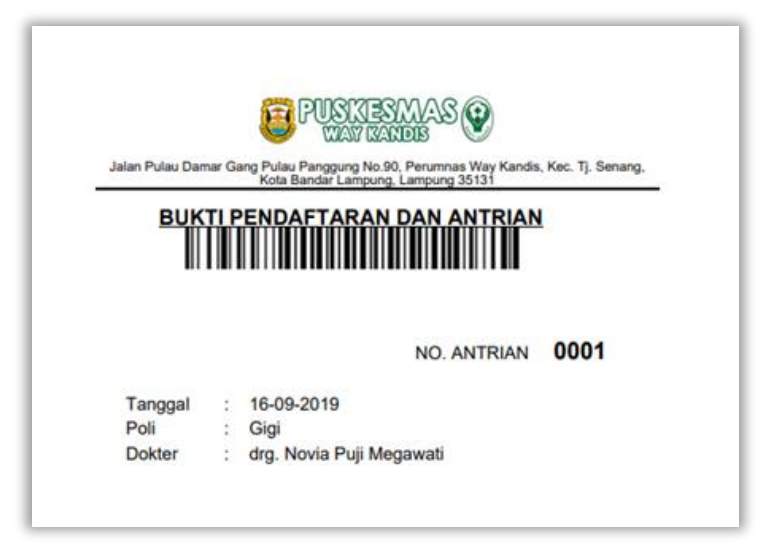

Gambar 9. Tampilan Hasil Cetak Antrian

\section{f. Tampilan Pendaftaran Hari Ini}

Tampilan ini berisi tentang pendaftaran pasien perhari. Tampilan ini berfungsi untuk menambah master data Adapun tampilan ini dapat dilihat pada gambar 10 berikut ini.

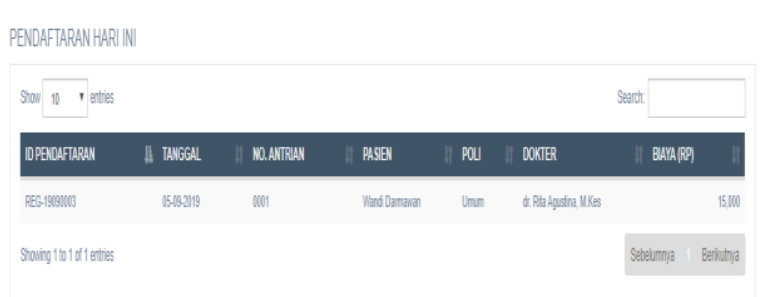

Gambar 10. Tampilan Pendaftaran Hari Ini

\section{g. Tampilan Master Data Pasien}

Tampilan berikut ini berisi data pasien yang terdiri dari id pasien, nama, ktp, jenis kelamin, tanggal lahir, dan alamat. Adapun tampilan ini dapat dilihat pada gambar 11 berikut ini.

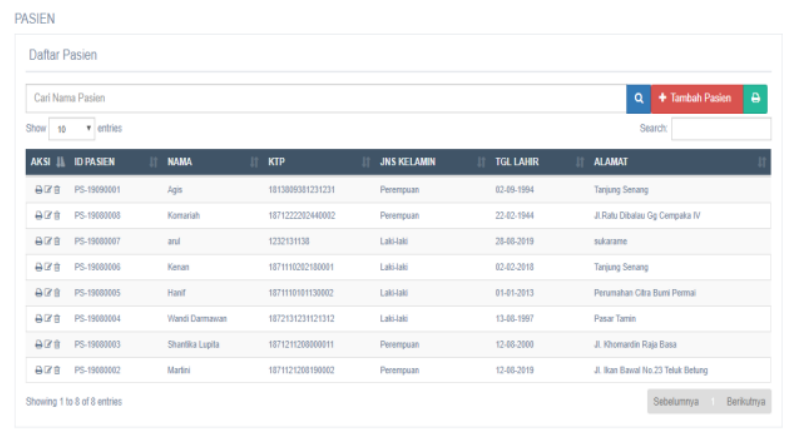

Gambar 11. Tampilan Master Data Pasien

\section{h. Tampilan Hasil Cetak Kartu Pasien}

Tampilan kartu pasien ini terdiri dari id pasien, nama, alamat, dan barcode. Adapun tampilan ini dapat dilihat pada gambar 12 berikut ini.

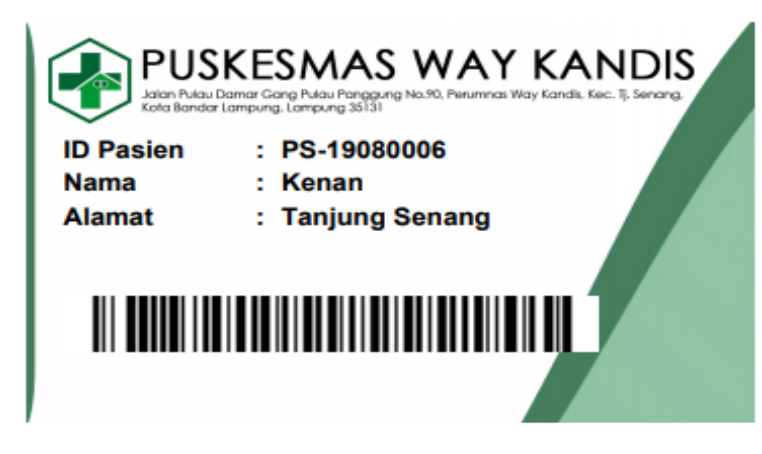

Gambar 12. Tampilan Hasil Cetak Kartu Pasien

\section{i. Tampilan Tambah Data Pasien}

10 pasien yang terdiri dari, id pasien, nama pasien, ktp, jenis kelamin, tanggal lahir, dan alamat. Adapun tampilan ini dapat dilihat pada gambar 13 berikut ini. 


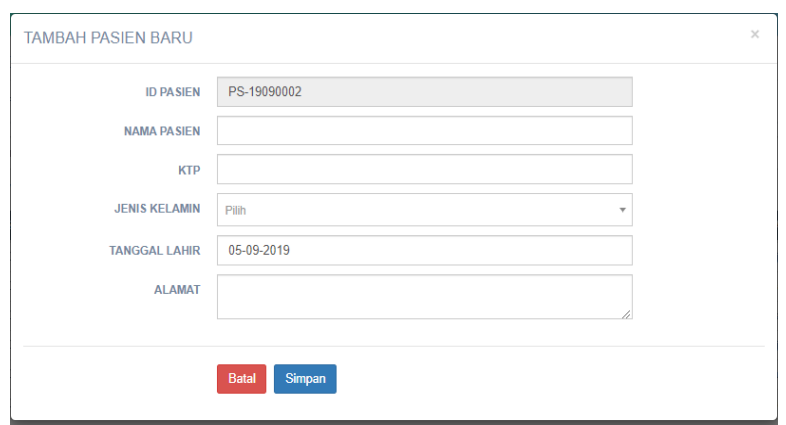

Gambar 13. Tampilan Tambah Data Pasien

\section{j. Tampilan Master Data Poli}

Tampilan berikut ini berisi daftar data poli yang terdiri dari, id poli, jenis poli, dan biaya. Adapun tampilan ini dapat dilihat pada gambar 14 berikut ini.

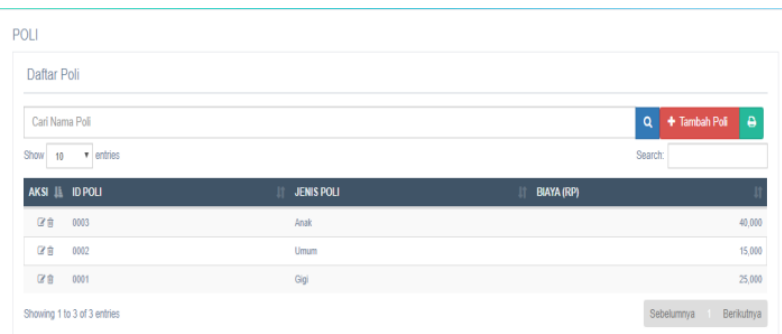

Gambar 14. Tampilan Master Data Poli

\section{k. Tampilan Tambah Data Poli}

Tampilan ini berfungsi untuk menambah master data poli yang terdiri dari, id poli, jenis poli, dan biaya. Adapun tampilan ini dapat dilihat pada gambar 15 berikut ini.

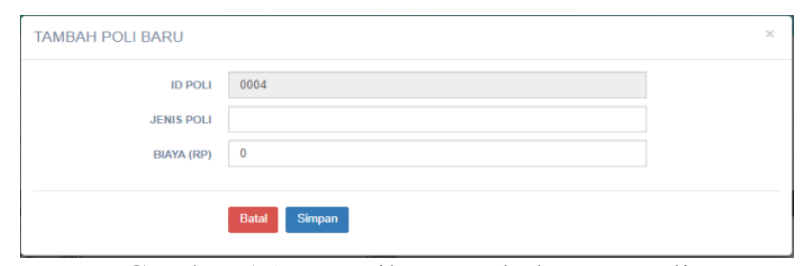

Gambar 15. Tampilan Tambah Data Poli

\section{Tampilan Master Data Dokter}

Tampilan ini berisi daftar data dokter yang terdiri dari, id dokter, nama, spesialis, alamat, dan telepon. Adapun tampilan ini dapat dilihat pada gambar 16 berikut ini :

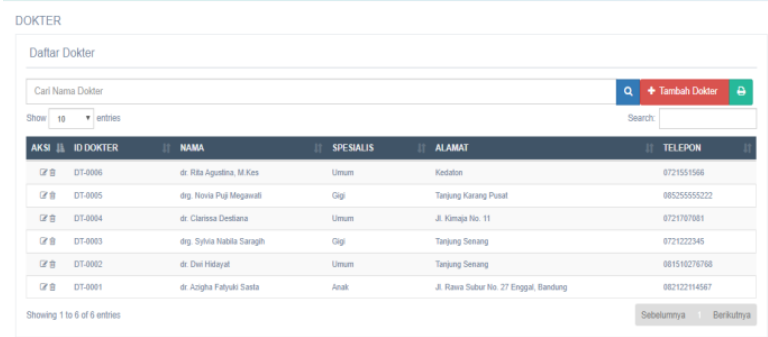

Gambar 16. Tampilan Master Data Dokter

\section{m. Tampilan Tambah Data Dokter}

Tampilan ini berfungsi untuk menambah master data dokter yang terdiri dari, id dokter, nama dokter, spesialis, alamat, dan telepon. Adapun tampilan ini dapat dilihat pada gambar 17 berikut ini.

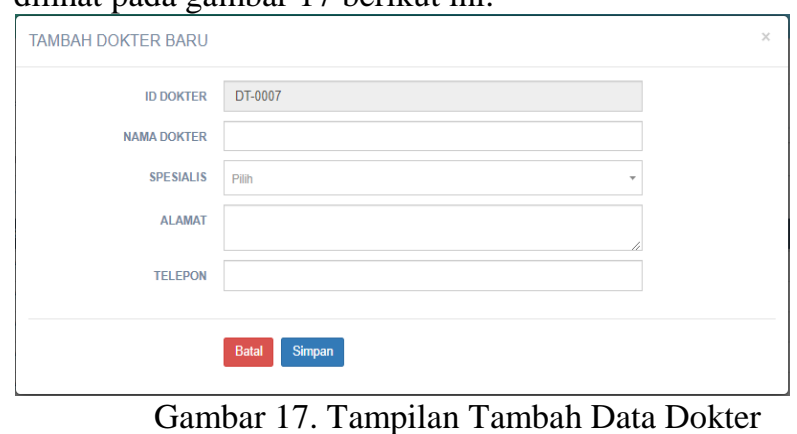

\section{n. Tampilan Profile}

Tampilan berikut ini adalah tampilan menu profile tentang Puskesmas Rawat Inap Way Kandis. Adapun tampilan dari menu profile terlihat di gambar 18.

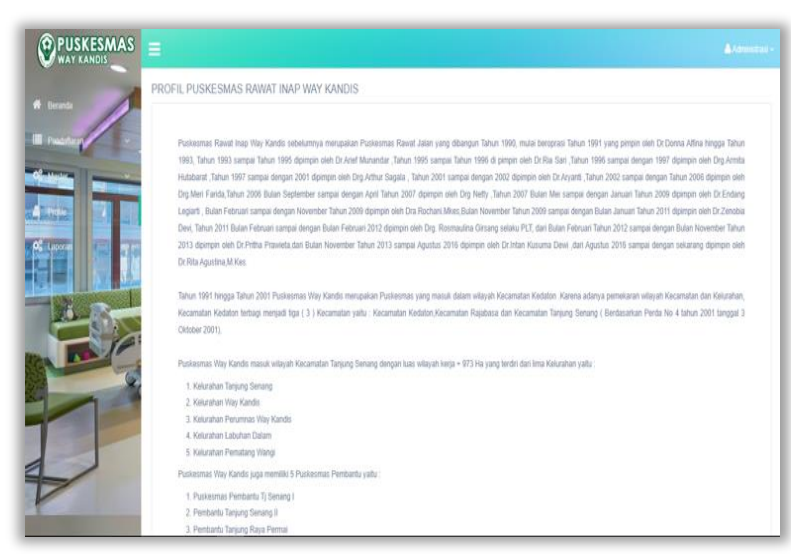

Gambar 18.Tampilan Profile

Pengujian sistem pada penelitian ini menggunakan black box dimana sistem yang dikembangkan pada Puskesmas Way Kadis dilakukan pengujian dengan cara pengentrian data oleh para aktor yang terlibat dalam proses rawat inap.

Tabel 1. Testing Input Data Pasien

\begin{tabular}{|c|c|c|c|}
\hline Kebutuhan & Testing Process & Hasil diinginkan & $\begin{array}{c}\text { Hasil } \\
\text { Test }\end{array}$ \\
\hline \multirow[t]{2}{*}{ Simpan } & $\begin{array}{l}\text { Data yang sudah } \\
\text { lengkap dan benar } \\
\text { disimpan }\end{array}$ & Data disimpan di tabel pasien & Sesuai \\
\hline & $\begin{array}{l}\text { Data yang belum } \\
\text { lengkap }\end{array}$ & Muncul pesan validasi & Sesuai \\
\hline \multirow[t]{2}{*}{ Edit } & $\begin{array}{l}\text { Data yang lengkap } \\
\text { dan benar diedit }\end{array}$ & $\begin{array}{l}\text { Data yang diedit diubah dan } \\
\text { disimpan di tabel pasien }\end{array}$ & Sesuai \\
\hline & $\begin{array}{l}\text { Data yang belum } \\
\text { lengkap diedit }\end{array}$ & $\begin{array}{l}\text { Data yang diedit tidak diubah } \\
\text { dan muncul pesan validasi }\end{array}$ & Sesuai \\
\hline Hapus & Hapus data pasien & $\begin{array}{l}\text { Data yang dihapus akan } \\
\text { terhapus di tabel pasien }\end{array}$ & Sesuai \\
\hline Cetak & $\begin{array}{l}\text { Menghubungkan ke } \\
\text { printer }\end{array}$ & $\begin{array}{l}\text { Data pasien dicetak pada } \\
\text { kartu pasien dengan barcode }\end{array}$ & Sesuai \\
\hline
\end{tabular}


Setelah dilakukan testing semua sesuai dengan hasil yang diinginkan.

\section{Kesimpulan}

Berlandaskan dari hasil penelitian dan penjelasan yang telah dijelaskan di bab hasil dan pembahasan tentang Sistem Informasi Pendaftaran Pasien Berobat Berbasis Barcode Scanner Pada Puskesmas Rawat Inap Way Kandis, diahasilkan kesimpulan sebagai berikut:

1. Dengan adanya Sistem Informasi Pendaftaran Pasien Berobat Berbasis Barcode Scanner yang dihasilkan dapat mempercepat penginputan, pengolahan data, dan pembuatan laporan. Efisiensi produk yang dihasilkan dapat meningkatkan kinerja lebih cepat di bagian pendaftaran.

2. Dengan adanya Sistem Informasi Pendaftaran Pasien Berobat Berbasis Barcode Scanner yang dihasilkan dapat mempermudah petugas admin pendaftaran dalam pelayanan terhadap pasien, hal ini meningkatkan efektivitas kerja dari admin.

\section{Daftar Rujukan}

[1] N. Fuji Astuti, "Manfaat Teknologi Informasi di Berbagai Bidang, Memudahkan Kehidupan Manusia," https://www.merdeka.com/jabar/manfaatteknologi-informasi-di-berbagai-bidangmemudahkan-kehidupan-manusia-kln.html, Dec. 30, 2020. (Access: 25 November 2021)

[2] Y. Andrika, "Penerapan Model Waterfall Pada Sistem Informasi Rawat Jalan Dengan Kartu Pasien Ber-Barcode Studi Kasus: Puskesmas Kenanga Sungailiat," Computatio: Journal of Computer Science and Information Systems, vol. 1, no. 2, 2017, doi: 10.24912/computatio.v1i2.1018.

[3] A. Aslam Fatkhudin and D. N. Alifiani, "SISTEM INFORMASI PENDAFTARAN PASIEN PADA KLINIK dr. VERI KAJEN KABUPATEN PEKALONGAN BERBASIS ANDROID," Edutic - Scientific Journal of Informatics Education, vol. 4, no. 1, 2017, doi: 10.21107/edutic.v4i1.3390.

[4] P. Andrianto, "Sistem Informasi Pelayanan Kesehatan Berbasis Web di Puskesmas," Jurnal Prosiding Seminar Nasional Komputer dan Informatika (SENASKI), vol. 2017, 2017.

[5] A. Syukron and N. Hasan, "Perancangan Sistem Informasi Rawat Jalan Berbasis Web pada Puskesmas Winong," Bianglala Informatika, vol. 3, no. $1,2017$.

[6] D. Abdullah and Iswandi, "Perancangan Sistem Pendaftaran Online Pasien Pada Klinik Dengan
Metode FIFO Berbasis Web Service," Techsi, vol. 6 , no. $1,2015$.

[7] D. Susianto, R. Astika, and Y. Syafitri, "Penerapan QR Code Untuk Media Pelayanan Absensi Mahasiswa AMIK Dian Cipta Cendikia," Jurnal ICT: Information Communication \& Technolog, vol. 20, no. 1, pp. 97-102, Jun. 2021.

[8] I. G. N. Suryantara, Merancang Applikasi dengan Metodologi Extreme Programming. Jakarta: Elex Media Komutindo, 2017. Accessed: Feb. 25, 2021. [Online]. Available: https://www.google.co.id/books/edition/Merancan g_Applikasi_dengan_Metodologi_Ex/FDBIDwAA QBAJ?hl=id\&gbpv=1\&printsec=frontcover

[9] Munawar, Analisis Perancangan Sistem Berorientasi Objek dengan UML, vol. 1. 2018.

[10] I. G. Partha SIndu and G. Yudhi Paramatha, Dasar Sistem Komputer. PT Raja Grafindo Persada, 2019.

[11] E. Ridhawati, Erlangga, and Y. Syafitri, "Digitalisasi Sistem Marketing Minyak Nilam Dengan Model Perancangan Berbasis Unified Approach Method," JURNAL SAINS DAN INFORMATIKA Research of Science and Informatic V7.I1, vol. 7, no. 1, pp. 29-35, Jul. 2021.

[12] A. Kamal, P. Anggraini, and Renita Astri, "Web Untuk Pengaduan Bagi Korban Kekerasan Terhadap Perempuan dan Anak," Jurnal Sains dan Informatika, vol. 4, no. 1, 2018. 